\title{
DISTRIBUSI RUMPUT LAUT ALAM BERDASARKAN KARAKTERISTIK DASAR PERAIRAN DI KAWASAN RATAAN TERUMBU LABUHANBUA, NUSA TENGGARA BARAT: STRATEGI PENGELOLAAN UNTUK PENGEMBANGAN BUDIDAYA
}

\author{
Erlania $^{\#}$ dan I Nyoman Radiarta \\ Pusat Penelitian dan Pengembangan Perikanan Budidaya \\ (Naskah diterima: 2 Juli 2015; Revisi final: 28 Agustus 2015, Disetujui publikasi: 2 September 2015)
}

\begin{abstract}
ABSTRAK
Keberadaan rumput laut di alam sangat dipengaruhi oleh karakteristik substrat dasar perairan. Penelitian ini bertujuan untuk menganalisis distribusi dan hubungan tutupan rumput laut alam dengan komponen substrat dasar perairan di sepanjang pantai Labuhanbua, Kabupaten Sumbawa. Pengumpulan data lapangan pada 46 titik pengamatan menggunakan transek kuadrat ukuran $1 \mathrm{~m}$ x $1 \mathrm{~m}$ yang ditempatkan sepanjang transek garis yang disebar tegak lurus terhadap garis pantai dengan jarak masing-masing sekitar $50 \mathrm{~m}$. Parameter yang diamati adalah: persentase tutupan dasar perairan yang terdiri atas tutupan pasir, karang hidup, pecahan karang, lumpur, batu karang, lamun, dan rumput laut (total tutupan 100\%). Pengambilan sampel substrat dasar perairan juga dilakukan pada beberapa titik pengamatan untuk analisa parameter $\mathrm{P}_{2} \mathrm{O}_{5}, \mathrm{~N}$ total, $\mathrm{C}$ organik total, dan tekstur substrat 3-fraksi: pasir, liat, dan debu. Analisis data dilakukan secara spasial dan statistik (analisis klaster dan deskriptif). Hasil penelitian memperlihatkan bahwa jenis Rhodophyta banyak ditemukan di kawasan dengan substrat dominan berlumpur; Chlorophyta pada substrat dengan asosiasi antara pasir, karang hidup, dan batu karang; sedangkan Phaeophyta lebih banyak ditemukan pada substrat dasar yang didominasi oleh pecahan karang. Secara keseluruhan, jenis-jenis dari kelompok Phaeophyta memiliki tutupan yang relatif jauh lebih tinggi dibandingkan Chlorophyta dan Rhodophyta. Strategi pengelolaan sumberdaya rumput laut alam dan pengembangan budidayanya dapat diimplementasikan melalui beberapa langkah penting, yaitu pengaturan pemanenan rumput laut alam, identifikasi jenis prospektif dan potensinya, pengembangan teknologi budidaya adaptif dan spesifik, serta studi kesesuaian lahan untuk pengembangan budidaya rumput laut potensial.
\end{abstract}

KATA KUNCI: distribusi spasial, rumput laut, substrat dasar, Sumbawa

ABSTRACT: Distribution of wild seaweeds based on sea bottom characteristics along reef flat area in Labuhanbua waters, West Nusa Tenggara: management strategy for aquaculture development. By: Erlania and I Nyoman Radiarta

The existence of wild seaweed is strongly influenced by bottom substrate characteristics. The study was conducted to analyse the distribution and relationship between wild seaweed coverage and bottom substrate components along Labuhanbua waters, Sumbawa Regency. Field data were collected using $1 \mathrm{~m} \times 1 \mathrm{~m}$ quadrate transect from 46 observation sites along line transects which were distributed perpendicular to the coast line and range about $50 \mathrm{~m}$ of each other. Observation parameters was percentage of sea bottom coverage which consist of coverage of sand, live coral, rubble, mud, rock, seagrass, and seaweed (total coverage 100\%). Sample of sea bottom substrate was also collected from several observation sites to analyse parameters included $\mathrm{P}_{2} \mathrm{O}_{5}$, total $\mathrm{N}$, total organic $\mathrm{C}$, and substrate 3fractions texture: sand, clay, and dust. Data were analysed using spatial and statistics methods (cluster and descriptive analysis). The result show that Rhodophyta species were mostly found in area dominated by muddy substrate; Chlorophyta in areas where the substrates were association of sand, rock, and live coral; whereas Phaeophyta in areas with rubble domination. Overall, species of Phaeophyta coverage were relatively much higher than Chlorophyta and Rhodophyta. Strategy of management and aquaculture development for wild seaweed resources can be implemented through several important actions, including arrangement of regulation for wild seaweed harvest, identification of prospective

\# Korespondensi: Pusat Penelitian dan Pengembangan Perikanan Budidaya. Jl. Ragunan No. 20, Pasar Minggu, Jakarta Selatan 12540, Indonesia. Tel.: + (021) 7805052

E-mail: erlania_elleen@yahoo.com 
species and its potencies, development adaptive and specifics cultivation technology, and also study of area suitability for potential seaweeds aquaculture development.

KEYWORDS: $\quad$ spatial distribution, seaweed, bottom substrate, Sumbawa

\section{PENDAHULUAN}

Rumput laut memegang peran penting secara biologi dan ekologi pada ekosistem laut. Pada kawasan pantai, rumput laut ditemukan di antara area pasang tertinggi dan surut terendah; dan pada kawasan subtidal ditemukan hingga kedalaman di mana jangkauan intensitas cahaya masih $0,01 \%$ dari kebutuhan cahaya fotosintesis (Domettila et al., 2013). Rumput laut alam ditemukan tumbuh subur pada permukaan batu karang di kawasan pasang surut sebagai hutan bawah laut; dan diperkirakan sekitar 200 spesies rumput laut menyangga perekonomian internasional terutama dari produk makanan dan fikokoloid yang nilainya lebih dari US\$ 6,2 (Satheesh et al., 2012; ZemkeWhite \& Ohno, 1999). Kabupaten Sumbawa memiliki sumberdaya kelautan dan perikanan yang cukup besar. Rumput laut merupakan salah satu kekayaan alam yang cukup berlimpah di kabupaten tersebut, di antaranya di perairan pantai Labuhanbua. Sumberdaya rumput laut alam yang ada di lokasi tersebut telah dimanfaatkan oleh nelayan setempat terutama dari jenis Sargassum. Aktivitas ini telah memacu peningkatan perekonomian masyarakat pesisir di lokasi tersebut.

Salah satu aspek yang memengaruhi distribusi dan keberadaan rumput laut alam adalah tipe substrat dasar perairan (Dadolahi-Sohrab et al., 2012; Satheesh \& Wesley, 2012; Kadi, 2004). Makroalga di alam hidup menempel pada substrat yang stabil untuk menjaga posisinya agar tidak hanyut terbawa oleh arus, gelombang, dan pasang surut. Karakter lingkungan perairan dengan kecepatan arus sedang merupakan kondisi yang baik untuk keberadaan rumput laut, sehingga pada lokasi tersebut dapat ditemukan rumput laut dengan biomassa yang lebih tinggi dibandingkan lokasi lain dengan karakter yang berbeda (Dadolahi-Sohrab et al., 2012).

Perhatian terhadap penurunan sumberdaya jenis rumput laut alam menjadikan studi taksonomi dan keanekaragaman jenis sangat penting untuk pengelolaan sumberdaya rumput laut yang lebih baik (Satheesh \& Wesley, 2012). Informasi yang dihasilkan dari studi distribusi dan keanekaragaman jenis rumput laut akan sangat membantu dalam berbagai aspek penelitian lainnya terkait kemudahan dalam pengumpulan jenis rumput laut tertentu di alam (Sahayaraj et al., 2014). Penelitian ini bertujuan untuk menganalisis distribusi dan hubungan tutupan rumput laut alam dengan komponen substrat dasar perairan di sepanjang perairan pantai Labuhanbua, Kabupaten Sumbawa. Hal ini dimaksudkan untuk mengetahui potensi rumput laut alam di kawasan tersebut serta strategi pengelolaan dan pemanfaatannya untuk kepentingan perekonomian masyarakat.

\section{BAHAN DAN METODE}

Penelitian telah dilakukan pada bulan September 2014 di pantai Labuhanbua, Kecamatan Utan, Kabupaten Sumbawa, Nusa Tenggara Barat (Gambar 1). Lokasi penelitian mempunyai potensi sumberdaya rumput laut alam yang cukup besar dengan kekayaan jenis yang beragam (Erlania et al., 2015). Rumput laut alam tersebut umumnya tumbuh di kawasan intertidal dengan kedalaman air berkisar antara 0-3 $\mathrm{m}$.

Pengumpulan data lapangan dilakukan pada 46 stasiun pengamatan di sepanjang kawasan intertidal pantai Labuhanbua dengan menggunakan transek garis yang disebar tegak lurus terhadap garis pantai. Pada setiap transek garis terdapat stasiun-stasiun pengamatan yang jumlahnya disesuaikan dengan kondisi dan karakteristik kawasan rataan terumbu yang disurvai (Papalia \& Arfah, 2013). Jarak antar stasiun pengamatan pada satu transek garis yang sama adalah sekitar $50 \mathrm{~m}$. Pengumpulan data pada setiap stasiun pengamatan dilakukan dengan menggunakan transek kuadrat berukuran $1 \mathrm{~m} \times 1 \mathrm{~m}$.

Data yang dikumpulkan meliputi data persentase tutupan dasar perairan pada setiap transek yang terdiri dari pasir, karang, pecahan karang, lumpur, batu karang, lamun, dan rumput laut (total tutupan 100\%). Dari total persentase tutupan rumput laut pada setiap transek kemudian dilakukan identifikasi jenisjenis rumput laut dan persentase tutupan dari setiap jenis rumput laut yang ditemukan pada setiap stasiun pengamatan (total tutupan $100 \%$ ). Identifikasi rumput laut alam di lokasi penelitian menggunakan Dhargalkar \& Kavlekar (2004) dan Kalsum (2012). Di antara 46 stasiun pengamatan rumput laut tersebut, dilakukan juga pengambilan sampel substrat dasar perairan pada sembilan stasiun. Metode pengambilan dan preservasi contoh substrat dasar perairan mengacu pada metode standar APHA (2005). Substrat dasar dianalisis di Laboratorium Tanah SEAMEO BIOTROP, Bogor untuk beberapa parameter yaitu total $\mathrm{P}_{2} \mathrm{O}_{5}$, total $\mathrm{N}, \mathrm{C}$ organik, dan tekstur tiga fraksi (komposisi pasir, debu, liat).

Data yang dikumpulkan dianalisis secara spasial dan statistik. Analisis spasial dilakukan dengan pe- 


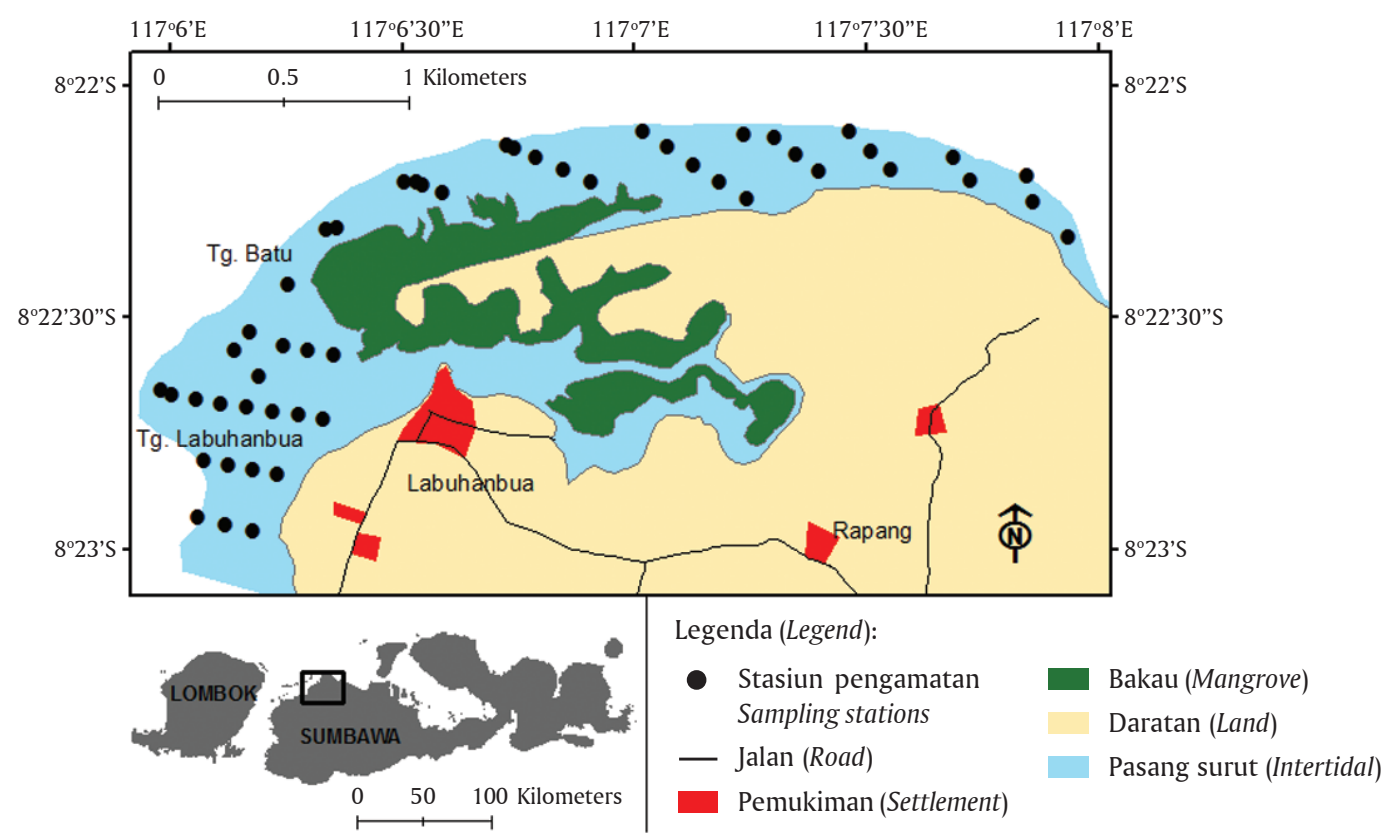

Gambar 1. Distribusi stasiun pengamatan pada kawasan intertidal pantai Labuhanbua, Sumbawa, Nusa Tenggara Barat

Figure 1. Distribution of research stations in Labuhanbua intertidal area, Sumbawa, West Nusa Tenggara

rangkat lunak ArcGIS versi 10. Analisis data untuk mengetahui hubungan antara distribusi rumput laut dengan tutupan dasar perairan dilakukan melalui analisis klaster (cluster analysis) dengan metode complete linkage menggunakan Minitab v.16. Seluruh hasil analisis data kemudian ditampilkan secara deskriptif dalam bentuk grafik dan gambar.

\section{HASIL DAN BAHASAN}

\section{Distribusi Tutupan Rumput Laut Alam dan Sub- strat Dasar Perairan}

Berdasarkan hasil pengamatan rumput laut di lapangan, variasi persentase tutupannya menunjukkan bahwa potensi rumput laut alam yang ada di rataan terumbu Labuhanbua relatif besar (Gambar 2). Distribusi dan kepadatan rumput laut alam dipengaruhi oleh tipe dasar perairan (substrat berlumpur, pasir kasar, batu karang) dan kondisi musiman dari aspek hidrografis, dan kompetisi jenis (Kadi, 2004). Selain rumput laut, komponen tutupan dasar perairan lainnya yang terdiri atas lamun, pasir, pecahan karang, karang hidup, dan batu karang di lokasi penelitian menunjukkan distribusi dan persentase tutupan yang cukup bervariasi. Hasil analisis distribusi tutupan dasar perairan memperlihatkan bahwa pada lokasi pengamatan dengan persentase tutupan rumput laut yang rendah/tidak ada $(0 \%-10 \%)$ ditemukan tutupan karang hidup dan lamun yang relatif tinggi yaitu mencapai $51 \%-100 \%$ (Gambar 2b dan 2d). Sementara itu, tutupan pasir umumnya hampir tersebar merata pada lokasi-lokasi di mana terdapat rumput laut (Gam- bar 2c). Tutupan rumput laut yang berbanding terbalik dengan karang hidup dan lamun, secara ekologi merupakan salah satu bentuk kompetisi interspesifik yang membatasi distribusi spesies yang berbeda untuk menempati relung ekologi yang sama (Kadi, 2004; Smith, 2013).

Berdasarkan hasil pengamatan pada 46 stasiun yang disebar di sepanjang pantai Labuhanbua, ditemukan 32 jenis rumput laut yang terdiri atas 13 jenis alga hijau (Chlorophyta), delapan jenis alga merah (Rhodophyta), delapan jenis alga coklat (Phaeophyta), dan tiga jenis lainnya yang belum dapat diidentifikasi. Secara umum, terlihat bahwa jenis-jenis dari kelompok Phaeophyta memiliki tutupan yang relatif jauh lebih tinggi dibandingkan jenis-jenis dari dua kelompok lainnya (Gambar 3). Tiga jenis yang memiliki tutupan terbesar dari kelompok alga hijau adalah Halimeda sp. (9,61\%); Halimeda simulans (4,34\%); dan Neomeris sp. (3,82\%). Untuk kelompok Rhodophyta, tiga jenis dominan yang ditemukan adalah Gracilaria salicornia (8,95\%), Eucheuma spinosum (3,95\%), dan Gracilaria foliifera (3,55\%). Sedangkan dari kelompok Phaeophyta adalah Padina sp., Hydroclathrus clathratus, Dictyota dichotoma merupakan jenis dominan dengan tutupan masing-masing $23,68 \%, 9,34 \%$, dan 5,79\%. Pada saat survai lapang, jenis Sargassum dari kelompok Phaeophyta, tidak terlalu banyak ditemukan yaitu hanya $2,89 \%$. Hal ini disebabkan karena saat survai dilakukan pada bulan September, komoditas Sargassum yang ada umumnya sudah dipanen oleh masyarakat di sekitar lokasi perairan. Nelayan di kawasan ini 

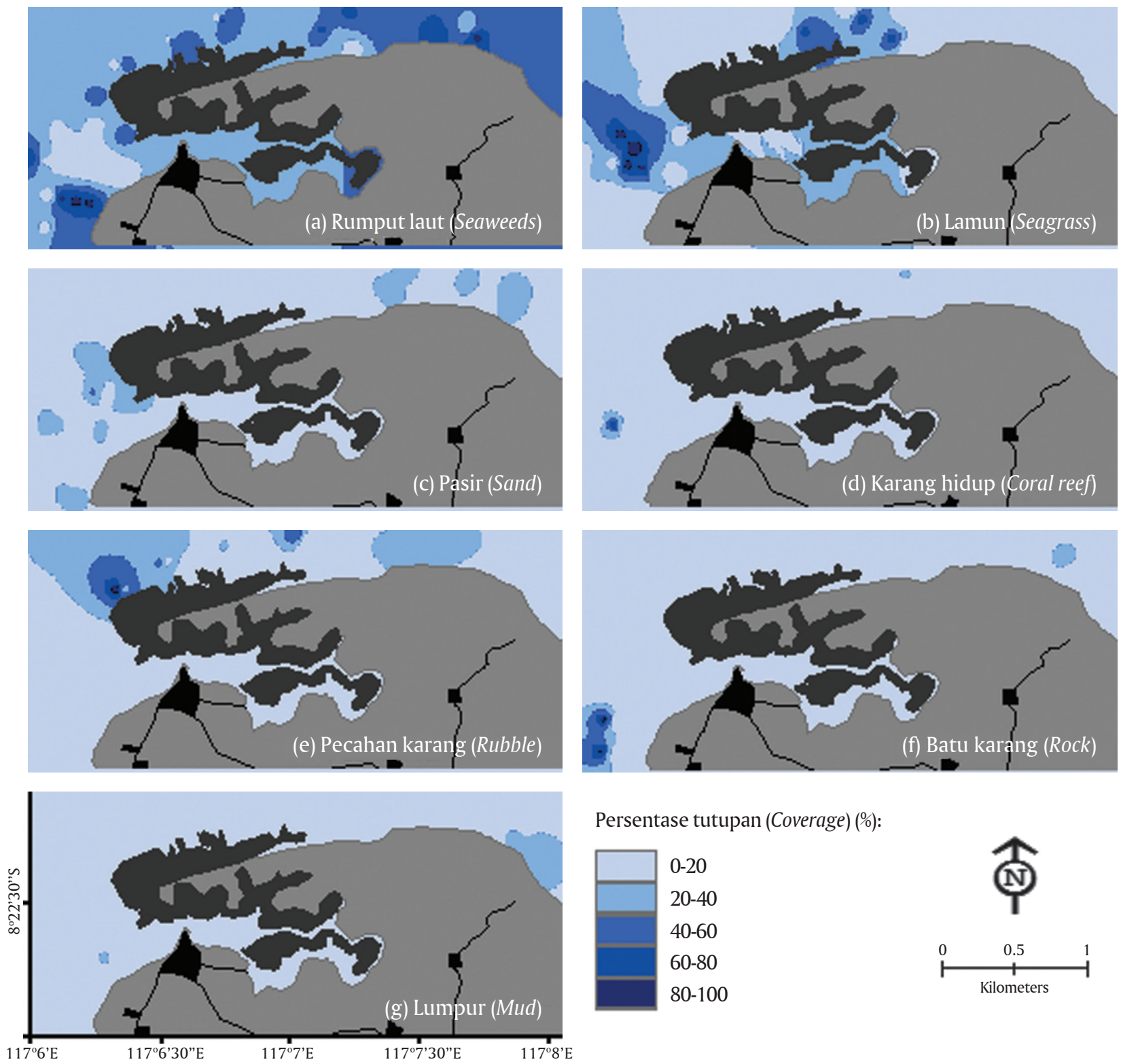

Persentase tutupan (Coverage) (\%):
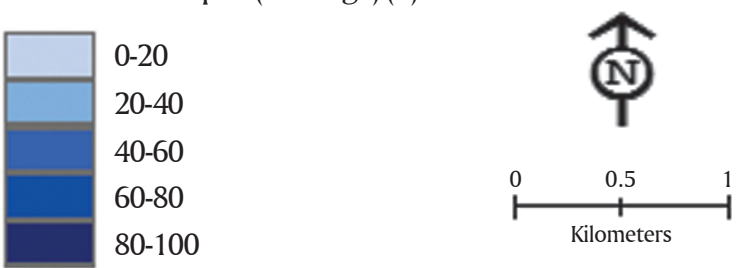

Gambar 2. Distribusi persentase tutupan rumput laut alam dan tutupan dasar perairan pada kawasan rataan terumbu di perairan Labuhanbua

Figure 2. $\quad$ Percentage of wild seaweed and bottom coverage distribution along reef-flat area in Labuhanbua waters

umumnya melakukan pemanenan rumput laut jenis Sargassum sp. sekitar bulan Februari-Juni (Erlania et al., 2015). Hasil pengamatan di lapangan menunjukkan bahwa Sargassum yang ditemukan umumnya berukuran kecil dengan panjang berkisar antara 5-25 cm.

\section{Hubungan Distribusi Rumput Laut terhadap Komposisi Substrat Dasar Perairan}

Hasil analisis klaster hubungan antara tutupan rumput laut dengan komponen tutupan dasar perairan lainnya ditampilkan pada Gambar 4. Berdasarkan dendogram yang dihasilkan terlihat bahwa distribusi dari tiga kelompok divisi rumput laut dipengaruhi oleh tipe/komponen substrat dasar perairan. Jarak dari klaster-klaster yang terbentuk merupakan hasil analisis terhadap korelasi antar variabel yang terdapat didalamnya (Gambar 4). Klaster-1 memperlihatkan bahwa kelompok Rhodophyta banyak ditemukan di kawasan dengan substrat dasar yang dominan berlumpur, di mana jenis-jenis dari kelompok ini juga ditemukan berasosiasi dengan ekosistem lamun. Berdasarkan hasil pengamatan di lapangan, jenis dari Rhodophyta yang dominan ditemukan pada lokasi dengan substrat berlumpur di antaranya yaitu Gracilaria sp. Sementara itu, jenis-jenis dari kelompok Chlorophyta ditemukan pada habitat dasar dengan tipe substrat berupa asosiasi antara pasir, karang hidup, dan batu karang yang diperlihatkan pada klaster-2; sedangkan pada klaster-3 terlihat bahwa jenis-jenis dari kelompok Phaeophyta lebih banyak ditemukan di 


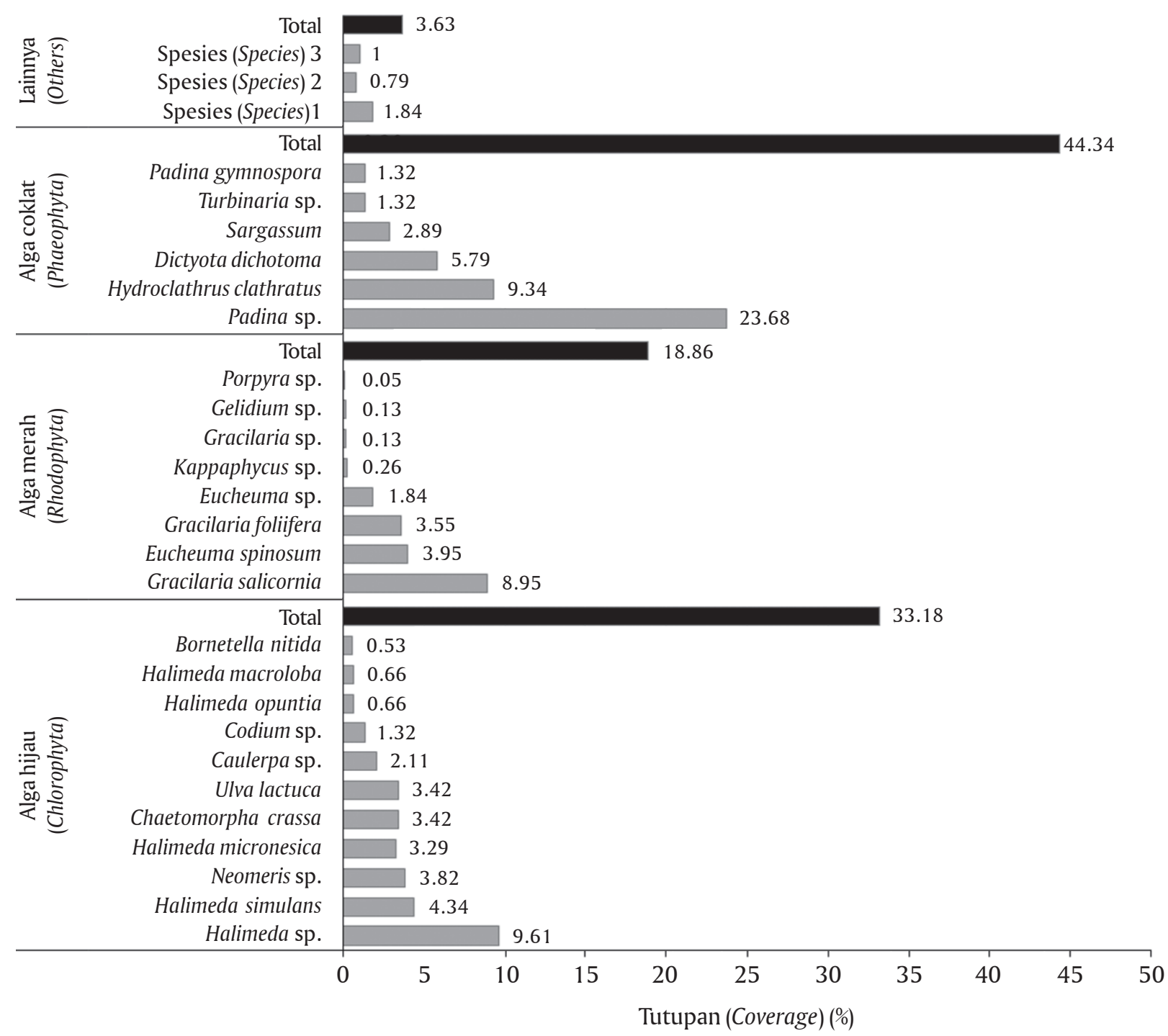

Gambar 3. Persentase tutupan dari jenis-jenis rumput laut alam pada kawasan rataan terumbu di perairan Labuhanbua

Figure 3. $\quad$ Percentage of wild seaweed species coverage along reef-flat area in Labuhanbua waters

daerah dengan substrat dasar yang didominasi oleh pecahan karang. Hal ini sesuai dengan pernyataan Dadolahi-Sohrab et al. (2012) bahwa distribusi dan dominansi jenis rumput laut membutuhkan habitat yang beragam dan berbeda-beda. Hasil penelitian Sahayaraj et al., 2014 menunjukkan bahwa keberadaan dan distribusi jenis-jenis rumput laut alam sangat dipengaruhi oleh musim dan posisi lintang lokasi perairan. Selain itu, variasi biomassa dan komposisi jenis rumput laut alam juga sangat dipengaruhi oleh musim yang umumnya terkait dengan toleransi jenis rumput laut terhadap suhu dan kekeringan (DadolahiSohrab et al., 2012)

Umumnya rumput laut hidup pada habitat dengan dasar perairan berpasir dan lumpur, di mana terdapat pecahan karang dan batu karang yang merupakan substrat bagi tempat tumbuh hampir semua jenis rumput laut dengan cara menancap, menempel atau mengikat partikel-partikel substrat tersebut. Substrat batu karang dapat dijumpai pada pulau-pulau yang mempunyai arus deras dan ombak besar; yang secara tidak langsung berfungsi untuk menahan erosi pantai. Menurut Kadi (2004), rumput laut yang tumbuh menancap di tempat berlumpur atau pasir-lumpur kebanyakan dari marga Halimeda, Avrainvillea dan Udotea; genus Caulerpa, Gracilaria, Eucheuma dan Acanthophora merupakan kelompok yang menempel pada pasir dan mengikat partikel-partikel pasir; sedangkan genus Gelidium, Gelidiopsis, Gelidiella, Hypnea, Laurecia, Hormophysa, Turbinaria, dan Sargassum merupakan kelompok alga yang umumnya melekat menggunakan holdfast berbentuk cakram, dan kebanyakan berada di daerah tubir. Holdfast merupakan struktur menyerupai akar pada rumput laut yang berfungsi seperti jangkar untuk menempelkan diri pada substrat. 


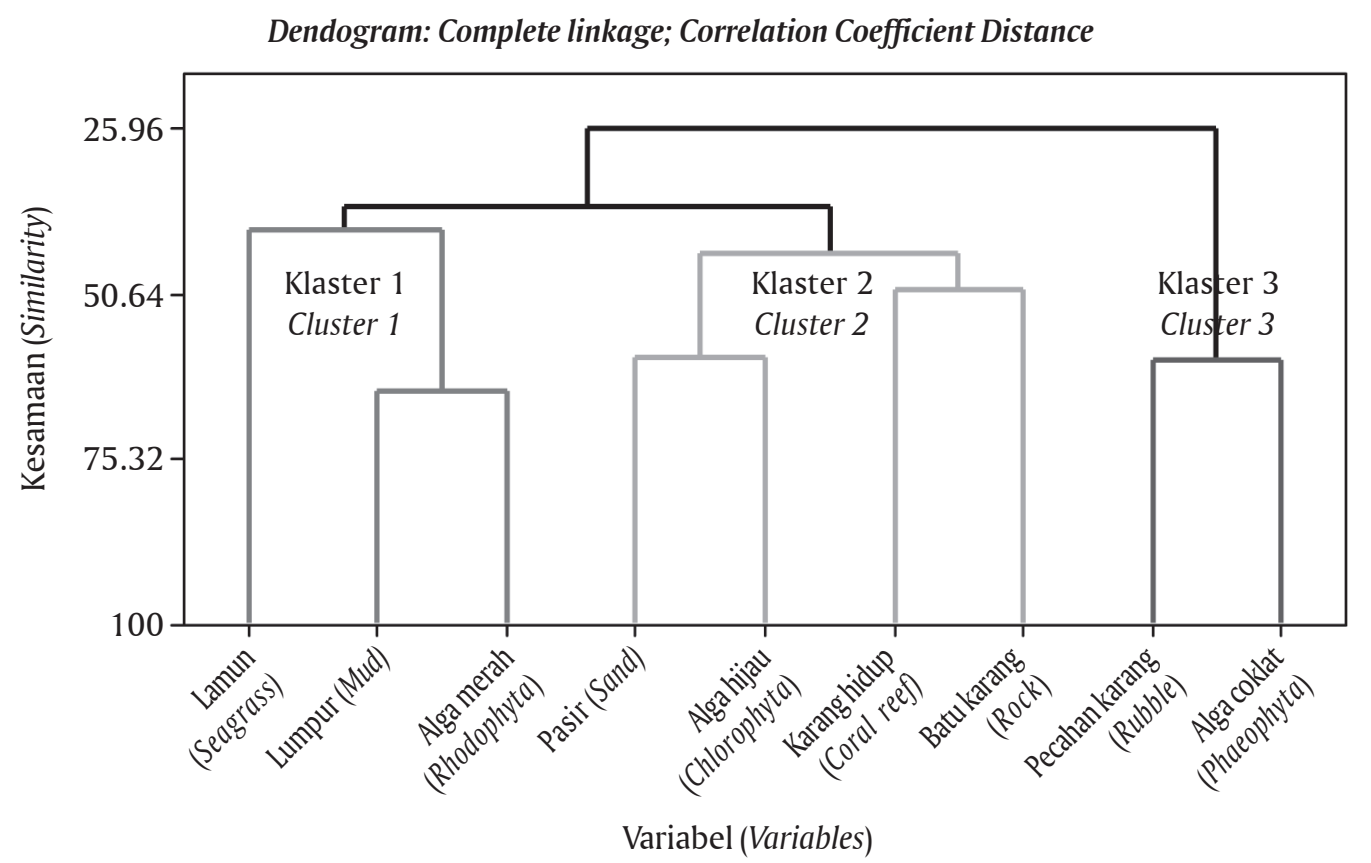

Gambar 4. Hasil analisis klaster hubungan distribusi tutupan divisi rumput laut dengan komponen tutupan dasar perairan lainnya di perairan Labuhanbua

Figure 4. Cluster analysis for correlation between seaweed division with other components of bottom coverage distribution in Labuhanbua waters

Hasil pengamatan fraksi substrat dasar perairan di beberapa titik transek menunjukkan bahwa komposisi fraksi substrat dasar didominasi oleh pasir dengan kisaran antara 73,8\%-98,3\% (Gambar 5). Jenis substrat pasir ini sangat mendukung untuk pertumbuhan jenis-jenis rumput laut yang dominan ditemukan di lokasi penelitian, antara lain: Halimeda sp., Gracilaria salicornia, dan Padina sp (Gambar 3). Jenis Halimeda sp. dan Padina sp. banyak ditemukan di kawasan dengan substrat pasir, pasir-berlumpur, dan pecahan-pecahan karang. Halimeda juga sering berasosasi dengan padang lamun (Kalsum,2012). Sedangkan Gracilaria sp. umumnya tumbuh dan berkembang dengan baik pada dasar karang atau batuan karang. Kondisi ini sangat sesuai dengan karakteristik kawasan rataan terumbu di lokasi penelitian, di mana pecahan karang, batu karang, dan pasir tersebar hampir merata di sepanjang kawasan tersebut (Gambar 2). Substrat yang kasar mencirikan arus yang kuat pada area tersebut sehingga umumnya menyebabkan

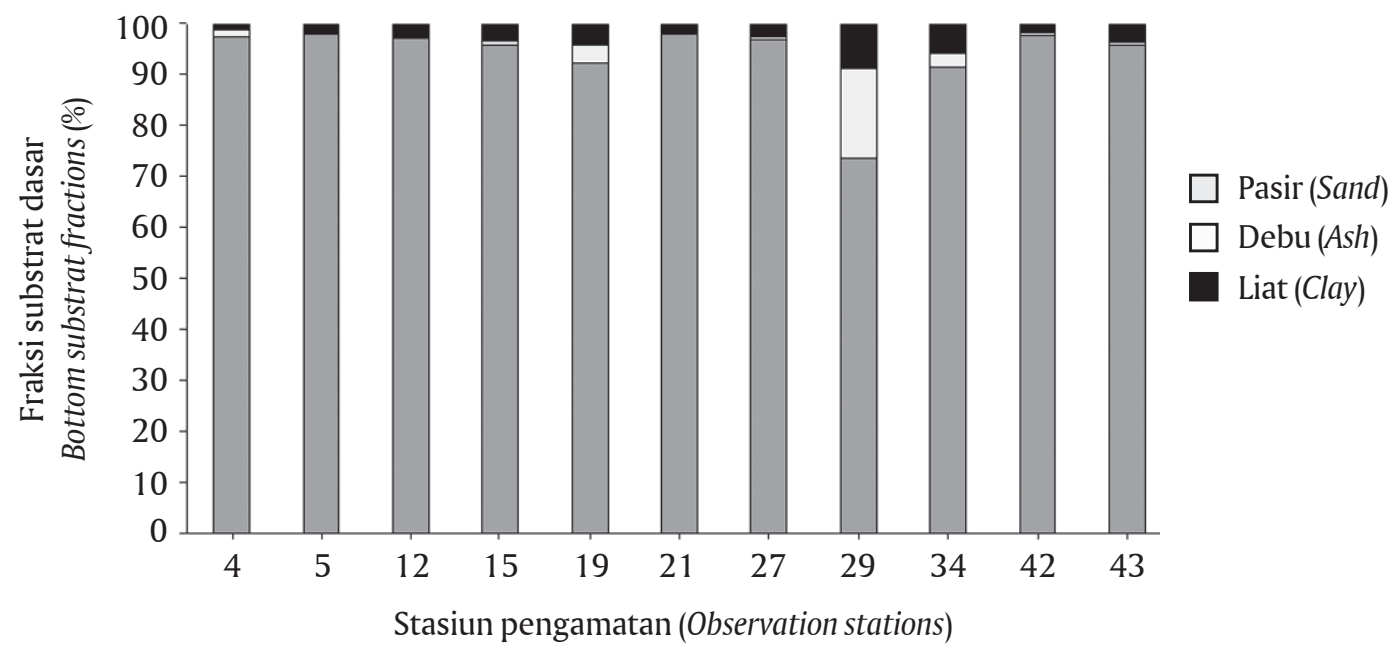

Gambar 5. Komposisi fraksi substrat dasar perairan pada beberapa titik pengamatan yang mewakili kawasan rataan terumbu Labuhanbua

Figure 5. Composition of bottom substrat fractions at several representative research stations in Labuhanbua waters 


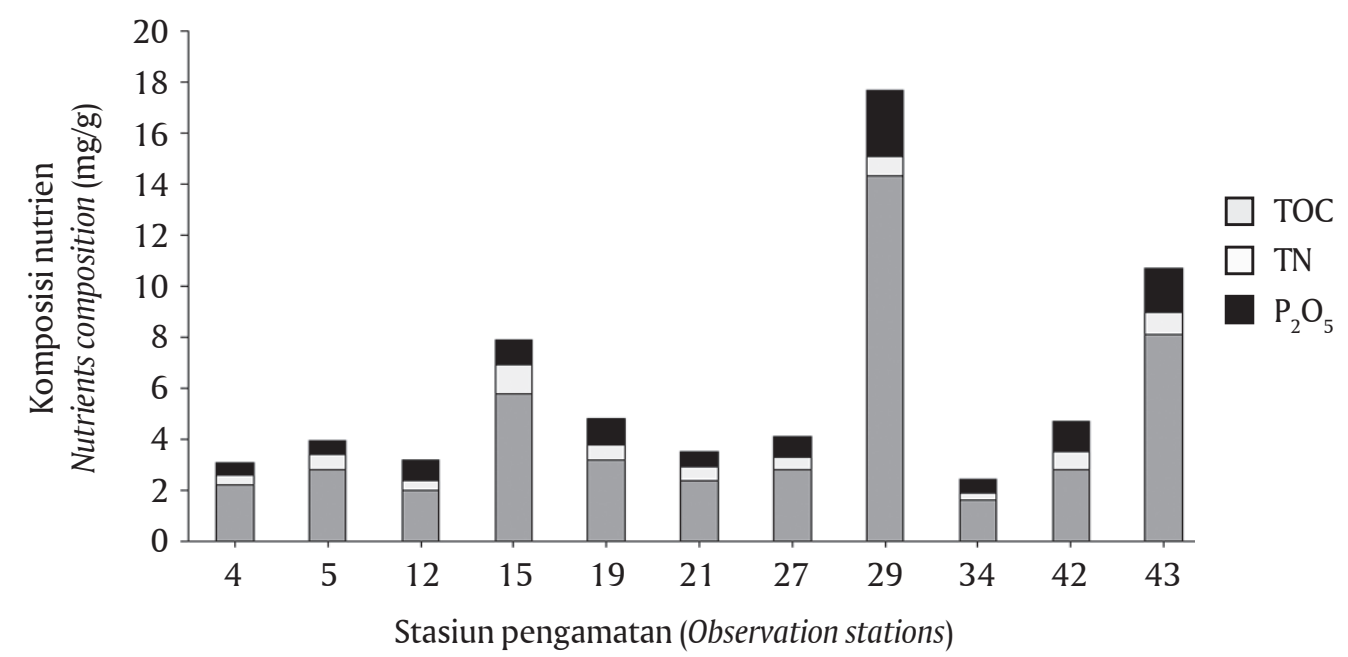

Gambar 6. Kandungan nutrien substrat dasar perairan pada beberapa titik pengamatan yang mewakili kawasan rataan terumbu Labuhanbua

Figure 6. Nutrient contents of bottom substrat at several representative research stations in Labuhanbua waters

rendahnya konsentrasi bahan organik dan miskin nutrien. Makroalga yang tumbuh menempel pada substrat memperoleh kebutuhan fosfor dan nitrogen dari sedimen; dengan demikian kecepatan arus yang berdampak pada ukuran partikel sedimen dan kandungan bahan organik, berpotensi sebagai faktor pembatas untuk pertumbuhan (Madsen et al., 2001).

Kondisi kualitas tanah/sedimen dasar perairan merupakan salah satu aspek yang mempengaruhi pertumbuhan dan sebaran rumput laut alam. Nutrien atau unsur hara yang terkandung pada sedimen dasar perairan yang diukur pada beberapa titik di sepanjang kawasan pantai Labuhanbua ditampilkan pada Gambar 6. Komposisi nutrien tertinggi dari substrat dasar perairan Labuhanbua adalah karbon organik yaitu berkisar antara 1,60-14,3 mg/g; sedangkan komposisi nitrogen total dan fosfat relatif lebih rendah. Kandungan nitrogen total dan fosfat pada substrat cukup bervariasi; nitrogen total berkisar antara 0,30 $1,10 \mathrm{mg} / \mathrm{g}$; dan fosfat yaitu berkisar antara $0,54-2,57$ $\mathrm{mg} / \mathrm{g}$. Kebutuhan nutrien rumput laut terbagi atas tiga kelompok yaitu: makronutrien, mikronutrien dan trace elements; N, P, dan C merupakan komponen makronutrien yang penting untuk pertumbuhannya (Harrison \& Hurd, 2001).

\section{Strategi Pengelolaan Sumberdaya Rumput Laut Alam dan Pengembangan Budidaya secara Berkelanjutan}

Potensi sumber daya rumput laut alam di Indonesia sangat besar dan ditemukan hampir di seluruh perairan pantai, baik di pulau-pulau besar maupun kecil. Saat ini, eksploitasi produksi rumput laut alam masih terbatas untuk jenis-jenis tertentu. Sementa- ra itu, pengambilan rumput laut alam untuk jangka panjang akan berdampak terhadap penurunan keseimbangan ekosistem pantai. Besarnya peranan rumput laut sebagai sumber dari berbagai substansi yang bernilai ekonomis tinggi, serta pertimbangan aspek keseimbangan ekosistem pantai, menjadikan komoditas ini sangat penting untuk dikembangkan. Selain itu, rumput laut merupakan salah satu komoditas yang akhir-akhir ini menjadi perhatian sehubungan dengan konteks karbon biru (blue carbon) dan penyerapan bahan organik dari perairan (Kaladharan, 2009; Chung et al., 2011; Erlania et al., 2013a; Erlania et al., 2013b; Erlania \& Radiarta, 2014).

Untuk menjaga keberadaan rumput laut di alam sekaligus membantu meningkatkan perekonomian masyarakat pesisir, maka diperlukan langkah-langkah strategis dalam pengelolaan dan pemanfaatan sumberdaya rumput laut sehingga fungsi dan manfaatnya dapat dirasakan oleh masyarakat dalam jangka panjang. Beberapa langkah penting yang dapat diambil di antaranya adalah:

\section{- Pengaturan pemanenan rumput laut dari alam}

Eksploitasi rumput laut dari alam oleh manusia secara besar-besaran tidak dapat dihindari pada saat masyarakat mulai menyadari manfaat dan nilai ekonomis dari berbagai jenis rumput laut tersebut. Oleh karena itu, perlu dilakukan pengaturan dalam hal pemanenan rumput laut alam melalui pendekatan oleh pemerintah daerah, baik melalui tokoh masyarakat maupun dengan penetapan regulasi pada tingkat daerah. Hal ini bertujuan untuk mencegah terjadinya eksploitasi rumput laut alam secara berlebihan, sehingga akan menyebabkan habisnya stok rumput 
laut di alam. Pengaturan ini dapat berupa penentuan waktu ataupun metode pengambilan/pemanenan yang sesuai, sehingga ekosistem rumput laut alam dapat pulih kembali. Kekayaan jenis rumput laut alam merupakan potensi besar yang dapat dikelola dan dikembangkan melalui penelitian dan pengembangan teknologi budidaya.

- Identifikasi jenis rumput laut alam prospektif dan potensinya secara spasial

Penyediaan data dan informasi secara spasial mengenai sebaran jenis rumput laut alam yang prospektif dan bernilai ekonomis tinggi akan sangat membantu dalam penghitungan potensi pemanfaatannya, baik dari sisi ekonomis maupun dari aspek karbon biru. Teridentifikasinya potensi kawasan rumput laut alam tersebut juga dapat dijadikan salah satu pertimbangan dalam penentuan tata ruang pengembangan wilayah pesisir, termasuk area pengembangan rumput laut melalui budidaya. Selain itu, dapat menjadi acuan dalam mempelajari karakteristik lingkungan yang spesifik untuk pengembangan teknologi budidaya dari jenis-jenis rumput laut potensial.

- Penelitian dan pengembangan teknologi budidaya rumput laut alam potensial

Ketersediaan rumput laut alam ekonomis penting seperti Sargassum sp., Gelidium sp., Caulerpa sp., Gracilaria sp., dan lainnya, sangat tergantung pada karakteristik perairan pantai dan pengaruh iklim. Oleh karena itu, perlu dilakukan penelitian untuk menghasilkan teknologi pengembangan budidaya rumput laut yang adaptif terhadap kondisi lingkungan, mencakup fluktuasi berbagai parameter kualitas air dan iklim. Berkembangnya teknologi budidaya jenis-jenis rumput laut alam tersebut, diharapkan dapat memberikan nilai tambah bagi masyarakat pesisir berupa peluang diversifikasi usaha, baik bagi nelayan ataupun pembudidaya. Dalam hal ini, dapat ditindaklanjuti dengan sosialisasi kepada masyarakat tentang jenis-jenis rumput laut alam yang memiliki nilai ekonomis penting beserta teknologi budidayanya. Kedepan, melalui penelitian dan pengembangan teknologi budidaya rumput laut, diharapkan produksi rumput laut akan lebih stabil dengan peningkatan kuantitas produksi dan kualitas rumput laut yang dihasilkan.

- Kajian kesesuaian lahan untuk pengembangan budidaya jenis-jenis rumput laut alam potensial

Karakteristik kawasan pesisir bersifat sangat dinamis dan spesifik antar lokasi perairan. Kajian kesesuaian lahan secara spasial sangat diperlukan untuk menentukan kawasan pesisir yang layak untuk pe- ngembangan budidaya dari berbagai jenis rumput laut alam potensial. Dengan demikian dapat ditentukan jenis rumput laut yang akan dikembangkan sesuai dengan karakteristik perairannya.

\section{KESIMPULAN}

Teridentifikasi sebanyak 32 spesies rumput laut di kawasan pantai Labuhanbua, Sumbawa yang termasuk dalam tiga divisi yaitu: Chlorophyta, Rhodophyta, dan Phaeophyta. Distribusi dari ketiga divisi rumput laut tersebut sangat dipengaruhi oleh tipe/ komponen penyusun substrat dasar perairan. Rhodophyta banyak ditemukan di kawasan dengan substrat dasar yang dominan berlumpur dan juga ditemukan berasosiasi dengan ekosistem lamun. Chlorophyta ditemukan pada habitat dasar dengan tipe substrat yang didominasi oleh pasir, karang hidup, dan batu karang; sedangkan Phaeophyta lebih banyak ditemukan di daerah dengan substrat dasar yang didominasi oleh pecahan karang. Strategi utama yang perlu dilakukan dalam pengelolaan sumberdaya rumput laut yang berkelanjutan, yaitu dengan mengatur waktu dan metode panen rumput laut alam. Selain itu diperlukan beberapa langkah penting untuk mencegah penurunan stok rumput laut alam dengan mengidentifikasi jenis rumput laut potensial, informasi spasial tentang keberadaan dan potensi rumput laut alam, kesesuaian lahan, serta pengembangan teknologi budidaya yang adaptif untuk jenis-jenis rumput laut alam potensial.

\section{UCAPAN TERIMA KASIH}

Penulis mengucapkan terima kasih kepada Dinas Kelautan dan Perikanan Kabupaten Sumbawa, NTB dan rekan peneliti Dr. Joni Haryadi dan Dr. Ofri Johan atas kontribusinya selama kegiatan lapangan. Penelitian ini dibiayai dari anggaran DIPA Pusat Penelitian dan Pengembangan Perikanan Budidaya tahun 2014.

\section{DAFTAR ACUAN}

APHA [American Public Health Association]. (2005). Standard Methods for the Examination of Water and Wastewater. $21^{\text {st }}$ Edition. American Water Works Association (AWWA)/American Public Works Association/Water Environment Federation, Washington. USA, 1,368 pp.

Chung, I.K., Beardall, J., Mehta, S., Sahoo, D., \& Stojkovic, S. (2011). Using marine macroalgae for carbon sequestration: critical appraisal. J. Appl. Phycol., 23, 877-886.

Dadolahi-Sohrab, A., Garavand-Karimi, M., Riahi, H., \& Pashazanoosi, H. (2012). Seasonal variations in biomass and species composition of seaweeds along the northen coasts of Persian Gulf (Bushehr 
Province). J. Earth Syst. Sci., 121, 241-250.

Dhargalkar, V.K., \& Kavlekar, D. (2004). Seaweeds-a field manual, National Institute of Oceanography. Dona Paula. Goa, 42 pp.

Domettila, C., Brintha, T.S.S., Sukumaran, S., \& Jeeva, S. (2013). Diversity and distribution of seaweeds in the Muttom coastal waters, south-west coast of India. Biodiversity Journal, 4(1), 105-110.

Erlania, Nirmala, K., \& Soelistyowati, D.T. (2013a). Penyerapan karbon pada budidaya rumput laut Kappaphycus alvarezii dan Gracilaria gigas di perairan Teluk Gerupuk, Lombok Tengah, Nusa Tenggara Barat. Jurnal Riset Akuakultur, 8(2), 287-297.

Erlania, Radiarta, I N., \& Sugama, K. (2013b). Peran budidaya rumput laut terhadap penyerapan karbon dan mitigasi perubahan iklim, Analisa Kebijakan Pembangunan Perikanan Budidaya 2013, Puslitbang Perikanan Budidaya, Badan Litbang Kelautan dan Perikanan, Kementerian Kelautan dan Perikanan, hlm. 11-20.

Erlania \& Radiarta, I N. (2014). Perbedaan siklus tanam budidaya rumput laut, Kappaphycus alvarezii, terhadap variabilitas tingkat serapan karbon. Jurnal Riset Akuakultur, 9(1), 111-124.

Erlania, Radiarta, I N., Haryadi, J., \& Johan, O. (2015). Kondisi rumput laut alam di perairan pantai Ujung Genteng, Sukabumi dan Labuhanbua, Sumbawa: potensi karbon biru dan pengembangan budidaya. Jurnal Riset Akuakultur, 10(2), 293-304.

Harrison, J., \& Hurd, C.L. (2001). Nutrient physiology of seaweeds: Application of concepts to aquaculture. Cah. Biol. Mar., 42, 71-82.
Kadi, A. (2004). Potensi rumput laut di beberapa perairan pantai Indonesia. Oseana, XXIX(4), 25-36.

Kaladharan, P., Veena, S., \& Vivekanandan, E. (2009). Carbon sequestration by a few marine algae: observation and projection. Journal of the Marine Biological Association of India, 51(1), 107-110.

Kalsum, S.J. (2012). Jenis-jenis rumput laut. Seaplant. net, $100 \mathrm{hlm}$.

Madsen, J.D., Chambers, P.A., James, W.F., Koch, E.W., \& Westlake, D.F. (2001). The interaction between water movement, sediment dynamics and submersed macrophytes. Hydrobiologia, 444, 71-84.

Papalia, S., \& Arfah, H. (2013). Produktivitas biomassa makroalga di perairan Pulau Ambalau, Kabupaten Buru Selatan, Jurnal Ilmu dan Teknologi Kelautan Tropis, 5(2), 465-477.

Sahayaraj, K., Rajesh, A., Asha, A., Rathi, J.M., \& Raja, P. (2014). Distribution and diversity assessment of the marine macroalgae at four southern districts of Tamil Nadu, India. Indian Journal of GeoMarine Sciences, 43(4), 607-617.

Satheesh, S., \& Wesley, S.G. 2012. Diversity and distribution of seaweeds in the Kudankulam coastal waters, South-Eastern coast of India. Biodiversity Journal, 3(1), 79-84.

Smith, D. (2013). Ecology of the New Zealand Rocky Shore Community: A Resource for NCEA Level 2 Biology. New Zealand Marine Studies Centre, 55 pp.

Zemke-White, W.L., \& Ohno, M. (1999). World seaweed utilization: An end of the century summary. Journal of Applied Phycology, 11, 369-376. 